\title{
THE ASSESSMENT OF DIRECT AGRICULTURAL INVESTMENT AND CASH TRANSFER ON HOUSEHOLDS IN MALAYSIA: AN EVIDENCE OF COMPENSATION MECHANISMS FOR FUEL SUBSIDY REMOVAL
}

\author{
Sze-Ying Loo* \\ Universiti Utara Malaysia \\ Mukaramah Harun \\ Universiti Utara Malaysia
}

\begin{abstract}
The objective of this study was to examine the impacts of introducing compensation mechanisms of direct agricultural investment and cash transfer for fuel subsidy removal, with particular focus on the income and consumption of all household segments in Malaysia. A computable general equilibrium (CGE) model was built on the basics of the standardized Löfgren CGE model to conduct this study. The subsidy removal, without integrating any compensation mechanism, imposed additional burdens of living cost on households as fuel was one of the important elements of the consumption basket especially during the period of transition, thus indicating a need for this study. The ultimate results revealed that the introduction of direct cash transfer was more desirable for both the low- and the medium-income segments to live with high prices where their existing consumption level would be maintained. Comparatively, the direct agricultural investment by increasing the use of intermediate inputs in the production did not seem to be enough to help the rural low-income segment within the period, mainly because of reducing the factor income (factor reallocation effect), and exaggerating consumption expenditure subsequently. Thus, direct cash transfer was considered a direct and faster way to help the needy in the short term. However, the direct agricultural investment remained the best approach to gain long-lasting impacts; not only in helping the rural poor, who mostly dealt in agricultural activities, but also in motivating overall economic activities.
\end{abstract}

Keywords: Fuel subsidy removal; Compensation mechanism, Saving reallocation on agricultural investment; Saving reallocation on direct cash transfer; Computable general equilibrium (CGE) model

Received: 21 May 2019

Accepted: 6 October 2019

\section{INTRODUCTION}

Undesirable impacts of fuel subsidies of distorting the energy market, leading to fuel overconsumption, burdening fiscal finance, and crowding out other priority public spending were the contributing factors driving fuel subsidy removal to be put on the top of the political agenda (IEA, 2013, 2015; Laderchi, 2014; Rentschler, 2016). A clear insight came, at a critical point, that the consequential price increases from the subsidy removal would greatly exaggerate the poor and

\footnotetext{
- Corresponding author: Loo Sze Ying, School of Economics, Finance and Banking, College of Business, Universiti Utara Malaysia, 06010 UUM Sintok, Kedah Darul Aman, Malaysia. Email: szeyingloo89@gmail.com
} 
low-income households who were struggling for subsistence through income and consumption channels (Arze del Granado, Coady, \& Gillingham, 2010; IMF, 2013; Laderchi, 2014; Coady, Parry, Sears, \& Shang, 2015; Harun, Sakkahuddin, \& Che Mat, 2018). Income distribution measures the fiscal policy effectiveness (Samanta \& Cerf, 2009; Harun, Zakariah, \& Azali, 2012; Dabla-Norris, Kochhar, Suphaphiphat, Ricka, \& Tsounta, 2015). Hence, it is important to acknowledge a place for a compensation mechanism to embody the distributive element of the subsidy reform where excessive subsidy savings could be generated to be reallocated to sound social safety nets.

Residents in Malaysia were no longer eligible to access low fuel prices when the government persisted in reducing the crowding-out public resources by removing the decades-old fuel subsidies to resolve the debt- burden issue. Retailed fuel prices have depended on market-based pricing regimes since then. All fuel prices has been changing every week since the end of March 2017, replacing the previous monthly fuel price adjustment that was introduced on 1 December 2014. This removal was expected to pose a significant challenge of unanticipated short-run increases in inflation where all economic decision-making are subject to actual prices (IMF, 2013; Laderchi, 2014), drawing the attention to the welfare issue that the poor and low-income households would be severely affected.

Ideally, this subsidy removal has to take the compensation mechanisms into consideration to maximize the population's benefit from the economy. A great bulk of empirical evidence showed a sizeable extra cost the households had to pay to maintain the existing consumption levels; decreasing real incomes from the subsidy removal pointed to an undeniable fact- a wise designation of a further saving reallocation that was able to shield the possible undesirable impacts that might happen (IMF, 2013; Laderchi, 2014; Siddiq, Aguiar, Grethe, Minor, \& Walmsley, 2014; Rentschler \& Bazilian, 2017). The extra savings, generated from the fuel subsidy removal, should be properly reallocated into strategic plans to create multiplier effects both in the short and the long run (Widodo, Sahadewo, Setiastuti, \& Chaerriyah, 2012). Implementing appropriate compensation mechanisms would increase public acceptance of the reform in the short term (Rentschler \& Bazilian, 2017). Experiences from several countries such as Gabon, Ghana, Indonesia, Jordan and Mozambique have revealed a better approach to implement the fuel subsidy reform successfully, using the fiscal integration of subsidy removal and social safety nets (Arze del Granado et al., 2010).

There is no one-size-fits-all strategy on matters of compensation mechanisms, but matching the approach to the social safety nets that benefit the poor is absolutely imperative in view of the ongoing future price increases (IEA, OPEC, OECD, \& World Bank, 2010; Dabla-Norris et al., 2015; Cockburn, Robichaud, \& Tiberti, 2018). The distribution of direct cash assistance to the vulnerable groups was the one being considered in this regard. The cash assistance became a popular aid where the targeted recipients received directly the cash and spent on whatever they wanted. Besides, the study also considered the rising government expenditure on agricultural activities under the fuel subsidy removal on account of two major concerns; as a source of raw materials for the domestic production system (Holland, Figueroa, \& Gilbert, 2001; Hena, Luan, Rehman, \& Zhang, 2019) and, most importantly, as a means to poverty eradication (CervantesGodoy \& Dewbre, 2010; Hena et al., 2019; Nejadrezaei, \& Ben-Othmen, 2019). 
The investment in agriculture, which is one of the rural development programs, can not only lead to a sustained growth in the level of production and productivity of all rural dwellers, but also sustain improvement in the community's well-being especially the farmers, reflected by the increasing per capita income and the standard of living (Nejadrezaei \& Ben-Othmen, 2019). Indeed, poor people in developing countries mostly rely on the agricultural sector as farmers who generally have low skills (Rehman, Luan, Khatoon, Iqbal, \& Hussain, 2016). Many schemes were introduced in Malaysia over the years aimed at reducing poverty to a satisfactory level and agricultural development was central to the developmental program of the rural areas through agencies such as FELDA, RISDA and MARA. The poverty rate in the rural areas was successfully reduced to 1.0 percent in 2016 compared with 58.7 percent in 1970. Nonetheless, urban earnings were 70 percent higher than rural earnings averagely (Khazanah Research Institute, 2018). Meanwhile, the income inequality for rural areas rose to 0.364 from 0.355 in 2014. Thus, developing the agricultural sector should remain as one of the items on the list of economic plans in view of the low government spending on the agricultural sector recently- only RM2191 (about 4 percent) out of RM54900 which was directed to this sector in $2018^{1}$.

Compared to previous studies, the contribution to knowledge in this study was in three aspects. First, households were disaggregated into six main categories by income both in the rural and the urban regions. This allowed the varying impacts of the fuel subsidy removal on different income segments, and the compensation mechanisms for helping the poor to be analyzed. Second, attention was given to the medium-income population besides the low-income population in the matter of cash distribution to the targeted population. Last and more importantly, the impact of imposing the fuel subsidy reform on households was analyzed in more detail where the changing income level and the consumption expenditure for these six categories were looked at.

The core objective of this study was to justify the effectiveness of the compensation mechanisms for the fuel subsidy removal on households using a developed computable general equilibrium (CGE) model that took direct and indirect price effects into account. This paper focused on two selected compensation mechanisms to support the livelihoods of the vulnerable households- the direct cash transfer approach to targeted households, and expanding agricultural investment. The structure of this study is as follows. Section 2 discusses the literature review. Section 3 illustrates the research methodology and framework, consisting of model closures, data sources and scenarios. Section 4 reports the results of the study and is followed by section 5 which contains the conclusion and recommendation of the study.

\section{LITERATURE REVIEW}

Numerous studies have shown that fuel subsidy removal adversely affected households in relation to income and consumption transmissions. Some studies linked the losses of income of households to the decreasing labor inputs used in the production in response to the fuel price hike (Hamid \& Rashid, 2012; Solaymani, Kari, \& Zakariah, 2013; Siddiq et al., 2014). Higher fuel prices create room for private investments in more energy-efficient technologies, influencing the labor demand which constitutes one of the important input factors. Besides, some studies connected the income losses to the increasing living costs due to high price effects (Bekhet \& Yusop, 2009; Arze del

\footnotetext{
${ }^{1}$ Retrieved from https://www.mea.gov.my/en/economic-statistics/public-sector
} 
Granado et al., 2010; Anand et al., 2013; Hakim, Ismail, \& Razak, 2014; Coady, Flamini, \& Sears, 2015; Harun, Mat, Fadzim, Khan, \& Noor, 2018). For example, with a cross-country evidence of 20 developing countries, Arze del Granado et al. (2010) claimed that a rise of $\$ 0.25$ per liter in fuel price led to 5.9 percent reduction in real household incomes, varying from 3.8 percent in South and Central America to 9.6 percent in the Middle East with a 6 percent increase of living cost (consumer price index-CPI increases). Bekhet and Yusop (2009), using an econometrical model, showed the reduction of household purchasing power in the form of CPI that firms passed higher costs on to households in a short time. All these circumstances were the consequences of direct (consuming fuels) and indirect (consuming other products that used fuel-intensive products) effects. Hakim et al. (2014) found that household real income in Malaysia was reduced by 10.7 percent for a 50.14 percent increase in fuel prices with a dominant indirect effect of about 65.0 percent.

With regards to the outcomes of the subsidy removal that discussed, compensation mechanisms have been suggested broadly, seeking to undertake the fuel subsidy reform to cushion the impacts of higher fuel prices on households. For example, Hamid and Rashid (2012) found that the government could generate an extra RM24 billion of revenue by increasing indirect taxes on the aggregate commodities of the petroleum refinery, and electricity and gas to remove the existing fuel subsidies. By using an integrated model of input-output (it was about a hybrid energy inputoutput matrix by adding a subsidy row to the adopted input-output table 2005) and CGE models for Malaysia, rechanneling these extra revenues into three optional strategies, covering the propoor, pro-wage and/or pro-growth ${ }^{2}$, would shoot up private investments to generate higher market benefits; but still, placing a substantial leftover revenue on the cash transfer scheme to the poor people was suggested, and claimed that it spurred productivity and enhanced welfare.

Widodo et al. (2012) also came to the conclusion that the government should consider not only the reallocation to the sectors approach (due to a relatively smaller positive effect than the negative effects of removing the fuel subsidy), but also a more targeted fuel subsidy which was a continuing compensation program for the poor such as the existing Bantuan Langsung Tunai (BLT) that takes regional perspectives into account. They simulated only the saving reallocation impacts of IDR1 billion for the fuel subsidy removal on four different sectors which consisted of the food, beverage and tobacco industry; agriculture; trade; and the education and health sectors using the Indonesian social accounting matrix 2008 data. The results indicated that the distributional impacts of the subsidy saving reallocation varied across households. Rural households, who depended mostly on agricultural activities, benefited most from the saving reallocation in the agricultural sector, while the urban upper-class households (working as entrepreneurs, teachers, managers, military and professionals) benefited most from the saving reallocation in the education and health sector.

Siddiq et al. (2014) put emphasis on the complete removal of imported fuel subsidy to create more fiscal space for a more preferable social plan in Nigeria if the target was poverty reduction. With the extra revenues, they demonstrated that household real incomes improved with increase rates of between 2.8 and 8.5 percent, carrying an average increase rate of 0.68 percent of private consumption for all rural households through the cash transfer scheme. By contrast, subsidizing the local petroleum product production decreased the factor returns of households, leading to a total disposal factor income decline. They concluded that rural households were likely to be

\footnotetext{
${ }^{2}$ For more details, kindly review the study of Hamid and Rashid (2012).
} 
affected by the higher prices of energy-intensive goods and services, while urban households were likely to be affected by higher petroleum product prices.

To determine the effectiveness of the fiscal policy by the great size of marginal propensity to consume (Dabla-Norris et al., 2015), most existing empirical studies were driven to support the further saving reallocation to the direct cash transfer scheme to protect the household current consumption level, especially the poor and the low-income households from high prices (Hamid \& Rashid, 2012; Widodo et al., 2012; Cooke, Hague, Tiberti, Cockburn \& El-Lahga, 2016, Sayed et al., 2015, Siddiq et al., 2015). Yet, reallocating the extra saving to the investments in the sectors approach was still being emphasized. Extending the saving reallocation to infrastructure and technological development for future development, for which direct cash transfers were inadequate to benefit the poor under the subsidy removal to gain long-term benefits (Rentschler, 2016; Akinyemi et al., 2017; Loo \& Harun, 2019).

Studies of mitigating the possible undesirable impacts, generated by the fuel subsidy removal, are limited in Malaysia. Thus, this study seeks to fill this gap by focusing on two compensation mechanisms which are extending agricultural investment and direct cash transfer that are widely encouraged by the existing studies. To do so, a CGE model was developed. The application of the CGE model in approaching the fuel subsidy removal is not new as it has been employed widely in subsidy-related studies in Malaysia such as Yahoo, Zulkeffeli, Rashid, and Puasa (2017) (examining the subsidy reduction on cooking oil), Solaymani et al. (2013), and Hamid and Rashid (2012) (integrated with the input-output model).

\section{METHODOLOGY}

\subsection{Framework of the CGE Model}

The International Food Policy Research (IFPRI) CGE modeling framework ${ }^{3}$ was employed in developing the used CGE model with a few modifications and assumptions to suit the objectives of the study. It is a neoclassical-structuralist modeling as presented in Dervis et al and originally formulated by Löfgren et al. (2012) to perform policy analysis in developing countries. The rationale behind this selection was its features for characterizing developing countries, such as activities were separated from commodities for production and leaving marketing costs out.

In the model, the separation between commodities and activities enabled a commodity to be produced by multiple activities, and an activity produced multiple commodities. An activity represented a producer who making few important decisions to maximize profits subject to production technology (factors' combination to balance the marginal revenue product and wages, which might be different across activities; input combination between intermediate inputs and factors to increase the efficiency of technology in the production process; and composite commodities (where imports were brought in together with domestic outputs as inputs) used in the output production). All ultimate commodities that produced were further allocated to the domestic

\footnotetext{
${ }^{3}$ Kindly review the document Lofgren, H., Lee, R.H., Robinson, S. (2002) “A standard computable general equilibrium (CGE) model in GAMS" for more details that is publicly available in the official page of International Food Policy Research Institute (IFPRI).
} 
market and exports subject to the constant elasticity of transformation (CET) function. With the ignorance of marketing costs, the supply price of domestic sales was equal to the price paid by domestic demanders. The export demand was infinitely elastic at a given world price.

The mechanism interactions in the economy in the model were mainly followed the IFPRI CGE model and some core equations were introduced in this paper. These equations were distributed into three blocks, consisting institution block, price, production and trade block, and system constraint block, as discussed below.

\section{(a) Institution Block}

This block defines all income and expenditure flows of inter-institutions. The household incomes in equation (1) were generated from factor income, transfer from the government and sometimes, wages from abroad. Specifically, equation (2) defines the total household consumption expenditure (the net value after allocating to direct taxes, savings and transfers to other domestic nongovernmental institutions).

$$
\begin{array}{ll}
Y H_{h}=\sum_{f \in F} Y I F_{h, f}+t r_{h, \text { gov }}+E X R \bullet t r_{h, \text { row }} & h \in H \\
E H_{h}=\left(1-\sum_{i \in I N S D N G} \operatorname{shii}_{i, h}\right) \bullet\left(1-M P S_{h}\right) \bullet\left(1-T I N S_{h}\right) \bullet Y I_{h} & h \in \mathrm{H}
\end{array}
$$

For the fiscal account, the government collects a variety of direct taxes, factor incomes and transfers from the ROW to generate its income (equation (3)), while spending the income on consumption and transfers to non-governmental institutions and the ROW (equation (4)).

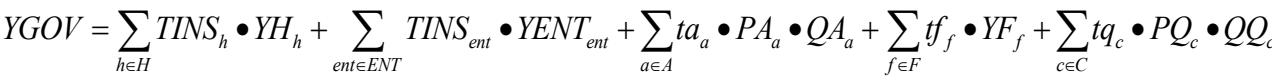

$$
\begin{aligned}
& +t r_{g o v, r o w} \bullet E X R+\sum_{f \in F} Y I F_{g o v, f}+\sum_{c \in C E} t e_{c} \bullet p w e_{c} \bullet Q E_{c} \bullet E X R+\sum_{c \in C M} t m_{c} \bullet p w m_{c} \bullet Q M_{c} \bullet E X R \\
& E G O V=\sum_{c \in C} P Q_{c} \bullet Q G O V_{c}+\sum_{i^{\prime} \in I N S D N G} t_{r n s f} r_{i, g o v} \bullet C P I
\end{aligned}
$$

\section{Price, Production and Trade Block}

The equation of composite price in equation (5) reveals the pay for the input combination of domestic output and import in domestic demand prices.

$$
P Q_{C} \bullet\left(1-t q_{c}\right) \bullet Q Q_{c}=P D_{c} \bullet Q D_{c}+P M_{c} \bullet Q M_{c} \quad \text { c } \in(\mathrm{CD} \mathrm{U} \mathrm{CM})
$$

Equation (6) is import price's equation. It was determined by using world import prices ( $p w m_{\mathrm{c}}$ ), exchange rate (EXR) and import tariff $\left(t m_{c}\right)$. Import price was assumed to be fixed in the model since Malaysia is a small country that does not have any power in affecting the world prices. Following this, equation (7) is the export price's equation. It was determined by world export prices $\left(p w e_{c}\right)$, exchange rate (EXR) and export tax $\left(t e_{c}\right)$.

$$
\begin{array}{ll}
P M_{C}=p w m_{c} \bullet E X R\left(1+t m_{c}\right) & c \in \mathrm{CM} \\
P E_{C}=\left(1-t e_{c}\right) p w e \bullet E X R & c \in \mathrm{CE}
\end{array}
$$


Equation (8) states the consumer price index (CPI). It was fixed and served as numéraire in the model.

$$
\overline{C P I}=\sum_{c \in C} P Q_{c} \bullet c w t s_{c}
$$

For the output production, two-level nested production function was adopted in the model. At the top-level production activity, the Leontief production function was employed (outputs were produced with the inputs of value-added and intermediate inputs were used in constant proportion), whereas the CES production function was employed at the bottom-level production activity (for the use of aggregate value added and intermediate inputs). Following this, the composite supply function is carried out by the Armington function in equations (9) and the constant elasticity of transformation (CET) function for the domestic outputs allocation on domestic sales and exports (the assumption of imperfect transformability was hold) in equation (10). Exponent $\rho$ in equation (9) is the elasticity of substitution between the domestic supply and import, while exponent $\rho$ in equations (10) is the transformation of the elasticity of substitution between domestic sales and exports.

$$
\begin{array}{ll}
Q Q_{c}=\alpha_{c}^{q} \bullet\left(\delta_{c}^{q} \bullet Q M_{c}^{-\rho_{c}^{q}}+\left(1-\delta_{c}^{q}\right) \bullet Q D_{c}^{-\rho_{c}^{q}}\right)^{-\frac{1}{\rho_{c}^{q}}} & c \in(\mathrm{CM} \cap \mathrm{CD}) \\
Q X_{C}=\alpha_{c}^{t} \bullet\left(\delta_{c}^{t} \bullet Q E_{c}^{\rho_{c}^{t}}+\left(1-\delta_{c}^{t}\right) \bullet Q D_{c}^{\rho_{c}^{t}}\right)^{\frac{1}{\rho_{c}^{t}}} & c \in(\mathrm{CE} \cap \mathrm{CD})
\end{array}
$$

\section{System Constraint Block}

This block presents all market balances in the model. The market balance in equation (11) encounters the total quantity demanded and the total quantity supplied (constant) for each factor. The market balance between quantities supplied and demanded of the composite commodity is brought out in equation (12). Equation (13) is the current-account balance to equal the country's earning and spending of foreign exchange. All ROW transactions were expressed in foreign currency. Since the foreign savings (FSAV) and trade deficit were exogenous in the marketclearing condition of the study, the flexible (real) exchange rate (EXR) determines the equilibrium of the current account.

$$
\begin{aligned}
& \sum_{a \in A} Q F_{f, a}=\overline{Q F S}_{f} \\
& Q Q_{c}=\sum_{a \in A} Q I N T_{c, a}+\sum_{h \in H} Q H_{c, h}+Q G O V_{c}+Q I N V_{c}+q d s t_{c}+Q T_{c} \\
& \sum_{c \in C M} p w m_{c} \bullet Q M_{c}+\sum_{f \in F} t_{r n s f r} r_{r o w, f}=\sum_{c \in C E} p w e_{c} \bullet Q E_{c}+\sum_{i \in I N S D} \text { trnsfr }_{i, \text { row }}+\overline{F S A V}
\end{aligned}
$$

\section{2. $\quad$ Model Closures}

There were 4 model closures determined each market's equilibrium, covering the factor, savinginvestment, the government and the ROW. In the factor market, the quantity of each supply factor was fixed but mobile under the full employment environment. Saving-driven investment was adopted for all non-government institutions. This means marginal propensity to save (MPS) was assumed constant and capital formation was flexible enough to adjust to equal to the saving value. Besides, flexible fiscal savings and fixed direct taxes were assumed in the government balance, allowing the government to reallocate the extra revenues from fuel subsidy removal on 
compensation mechanism in the study with the same amount. Thus, the ultimate real fiscal balance was determined by the fiscal revenue. Current-account balance (the difference between foreign currency spending and receipt) was held constant and the exchange rate was flexible based on the closure choice for the ROW. To conduct an analysis for the short-run period, it was appropriate to hold the exchange rate constant. Therefore, only exports and imports did matter for foreign balance market.

\subsection{Data Sources}

The main database for constructing this CGE model was the social accounting matrix (SAM), which was built using the input-output table for the base year of 2010. Thus, the base year of the benchmark simulation model was year 2010. Besides, the Household Expenditure Survey (HES) and Household Income Survey (HIS) for year 2009, national account statistics, which are yearly national products and expenditure accounts, balance of payments, together with distribution and use of income accounts and capital accounts, were used simultaneously. The SAM model is slightly different to those that was developed in Harun, Zakariah and Azali (2012) and Hassan, Saari, Utit, Hassan and Harun (2016), in that the separation of commodities and activities (represents a producer) are employed in this study. The model consisted of activities, commodities, factors (labor and capital), households, firms, the government, saving-investment and the rest of world (ROW). Households, the focus of the study, were grouped into rural high-, rural medium-, rural low-, urban high-, urban medium- and urban low-income groups. These household income groups (for both rural and urban areas) were the distribution of the top 20 percent, middle 40 percent and bottom 40 percent as stated by the Department of Statistics Malaysia. Factor incomes that derived from supplying factors of production, and transfers from other institutions, were then spent on consumption, savings, tax payments, and sometimes, transfer to other institutions.

The developed SAM model not only determined the CGE modeling framework, but also those parameter values and exogenous element. Other elasticity values such as elasticity of substitution between capital and labor, and output allocations have been taken mainly from Solaymani et al. (2014). All prices in the CGE model were assumed to be one at the initial equilibrium level.

\section{4. $\quad$ Simulated Scenarios}

The household impact of introducing compensation mechanisms for fuel subsidy removal was examined using three simulations. All the ultimate findings are discussed and compared with the base calibration year in the next section. The three simulations were:

(1) Abolishing the government fuel subsidy in full, without any compensation mechanism (before the introduction of compensation mechanism).

(2) Abolishing the government fuel subsidy in full and reallocating this extra savings into direct transfer payments for both low- and medium-income segments.

Abolishing the government fuel subsidy in full and reallocating this extra savings into agricultural investment (by adding more intermediate inputs used in the production).

The fuel subsidy was removed by increasing sales tax rate in the petroleum refinery sector with equal proportions of the subsidy reduction. The government expenditure on fuel subsides in 2010, amounting to RM9605 million was taken into account. Following this, the same amount of extra savings from the fuel subsidy reform was reallocated into two selected compensation mechanisms. 
These simulation scenarios were conducted under a few model assumptions such as all markets operate in a prefect competitive condition, and only relative price and market-clearing conditions matter. Besides, all mathematical equations were solved using the General Algebraic Modeling System (GAMS) software.

\section{RESULTS AND DISCUSSION}

\subsection{Effects of Introducing the Compensation Mechanism on Household Incomes}

Table 1 pictures the changes in the household incomes, before and after introducing the compensation mechanisms into the subsidy removal. All value changes were defined in real terms, that is, adjusted for the rate of change of CPI. The results showed that the subsidy removal reduced the real incomes of all household segments in the short run due to the consequential higher fuel prices without any compensation mechanism. In Simulation 2 that included the compensation mechanism of direct cash transfer to targeted households, real incomes for all low- and mediumincome households decreased greatly, ranging from a 14.24 percent decrease for rural mediumincome households to a 15.18 percent decrease for urban low-income households. Comparatively, in Simulation 3 that introduced the compensation mechanism of government transfer to the agricultural sector through an incremental consumption of intermediate inputs used in the production, exaggerated the real income decreases of low-income households compared to the base scenario of fuel subsidy removal without imposing any compensation mechanism. However, the degree of real income decreases for low-income households remained lower than when the direct cash transfer was introduced to the fuel subsidy removal. These circumstances indicate that Simulation 3 is considered the best policy for improving household incomes, albeit it takes longer to gather the positive effects where workers need to be trained and equipped with all the necessary knowledge and skills to be ready for the industrial technological change, especially for the rural poor who are generally low-skilled workers. In Simulation 2, real household incomes declined largely due to the high price level.

Table 1: Changing Household Incomes (in percent)

\begin{tabular}{lrrr}
\hline \hline \multicolumn{1}{c}{ Description } & SIM 1 & SIM 2 & SIM 3 \\
\hline Urban low-income households & -10.52 & -15.18 & -10.99 \\
Urban medium-income households & -11.11 & -14.72 & -10.19 \\
Urban high-income households & -11.53 & -11.54 & -10.30 \\
Rural low-income households & -10.73 & -14.39 & -11.94 \\
Rural medium-income households & -11.01 & -14.24 & -10.72 \\
Rural high-income households & -11.21 & -11.22 & -10.57 \\
\hline \hline
\end{tabular}

Source: Author's calculation based on the developed CGE model.

\subsection{Effects of Introducing the Compensation Mechanism on Household Consumption Expenditure}

Table 2 depicts the changes in the household consumption expenditure before and after introducing the compensation mechanisms into the subsidy removal, holding the rate of change of the CPI constant. The household consumption expenditure was the leftover incomes, after the deduction of 
all the needed tax payments and savings, that were readily available for spending. The results showed that the subsidy removal decreased the consumption expenditure of all household segments in the short run as a result of the fuel price hike without integrating any compensation mechanism. The introduction of the compensation mechanism of direct cash transfer in Simulation 2 was found to enhance the bad effect brought by the subsidy removal (SIM 1) on the household consumption expenditure of low- and medium-income households. Comparatively, the agricultural investment in Simulation 3 improved the decreases in consumption expenditure for all household segments significantly except for the rural low-income households with a 12.29 percent decrease compared to the 11.43 percent decrease in SIM 1. With the introduction of direct cash transfer to the subsidy removal, household purchasing powers increased, mainly caused by the government direct transfers in their base incomes, permitting them to preserve the current consumption level before making any consumption adjustment. In SIM 1 and SIM 2, household consumption expenditure declined due to the decreases in factor incomes (profits and wages), which brought a reduction in the leftover incomes that were readily available for spending.

Table 2: Changing Household Consumption Expenditures (In Percent)

\begin{tabular}{llll}
\hline \hline \multicolumn{1}{c}{ Description } & SIM 1 & SIM 2 & SIM 3 \\
\hline Urban low-income households & -11.28 & -10.94 & -11.26 \\
Urban medium-income households & -11.87 & -11.60 & -10.69 \\
Urban high-income households & -12.31 & -12.31 & -10.77 \\
Rural low-income households & -11.43 & -11.16 & -12.29 \\
Rural medium-income households & -11.78 & -11.54 & -11.14 \\
Rural high-income households & -12.08 & -12.08 & -11.16 \\
\hline \hline
\end{tabular}

Source: Author's calculation based on the developed CGE model.

\section{CONCLUSION}

This study focused on the effect of the effectiveness of the agricultural investment and direct cash transfer as mitigating measures on income and consumption expenditure at the household level in Malaysia. Based on the findings, the implementation of the fuel subsidy removal without any compensation mechanism would expose all households to the risk of reducing real incomes, distorting consumption expenditure. The high-income population with higher shares of their budgets placed on fuel consumption was more likely to experience a much higher rate of reductions in contrast to the low- and medium-income population.

To protect those who were less desirable to absorb the high costs, the introduction of direct cash transfer to the subsidy removal was found to have effectively helped the targeted households in the short run. The additional nominal incomes enabled the receivers to temporarily maintain the living standards before changing their attitudes towards consumption. Nonetheless, high inflation rates might occur, manifested in the declining real incomes for all households where the existing suppliers were not able to promptly respond to this increased demand. Thus, the implication of this aid should be designed based on careful consideration. Expanding domestic agricultural investment would be the best policy to reduce poverty, particularly in rural regions. A growth in the agricultural sector can effectively lead to a two to four times more rise in incomes among the poorest compared to other sectors (World Bank, 2019). Also, the growth in the agricultural sector 
would further have a great impact on extended sectors with high linkages between the sectors, spurring overall economic prosperity although an extended time period is required to gain such evidence (Holland, Figueroa, \& Gilbert, 2001; Bekhet, 2010; Thiessen, 2015).

The fuel subsidy removal was always a much difficult task to impose that required efforts at times. Nevertheless, it is often considered a favorable way to direct a country to achieve a sustainable economic growth in the future as the availability of a large bulk of fuel subsidy tends to overshoot fiscal budget allocations, crowding-out other productive investments. The further additional revenue from the fuel subsidy removal could get back to the agricultural sector that has strategic functions in the economic development - place the agricultural investments as one on the list of the agenda of economic plans. The modernization of the agricultural sector should be given focus to ensure all domestic agricultural skills and practices are keeping pace with the times.

\section{REFERENCES}

Akinyemi, O., Alege, P. O., Ajayi, O. O., Adediran, O. S., \& Urhie, E. (2017). A simulation of the removal of fuel subsidy and the performance of the agricultural sector in Nigeria using a dynamic Computable General Equilibrium Approach. Covenant Journal of Business and Social Sciences, 8(1), 60-70.

Anand, R., Coady, D., Mohammad, A., Thakoor, V., \& Walsh, J. P. (2013). The fiscal and welfare impacts of reforming fuel subsidies in India (IMF Working Paper No. WP/13/128). Washington, DC: International Monetary Fund. Retrieved from https://www.imf.org/en/ Publications/WP/Issues/2016/12/31/The-Fiscal-and-Welfare-Impacts-of-ReformingFuel-Subsidies-in-India-40593

Arze del Granado, J., Coady, D., \& Gillingham, R. (2010). The unequal benefits of fuel subsidies: $A$ review of evidence for developing countries (IMF Working Paper No.WP/10/202). Washington, DC: International Monetary Fund.

Bekhet, H. A. (2010). Ranking sectors changes of the Malaysian economy: Input-output approach. International Business Research, 3(1), 134-143.

Bekhet, H. A., \& Yusop, N. Y. M. (2009). Assessing the relationship between oil prices, energy consumption and macroeconomic performance in Malaysia: Co-integration and vector error correction model (VECM) approach. International Business Research, 2(3), 152175.

Cervantes-Godoy, D. \& Dewbre, J. (2010). Economic importance of agriculture for poverty reduction (OECD Food, Agriculture and Fisheries Working Papers, No. 23). Paris, France: Organisation for Economic Co-operation and Development.

Coady, D., Flamini, V., \& Sears, L. (2015). The unequal benefits of fuel subsidies revisited: Evidence for developing countries (IMF Working Paper No. WP/15/250). Washington, DC: International Monetary Fund.

Coady, D., Parry, I., Sears, L., \& Shang, B. (2015). How large are global energy subsidies (IMF Working Paper No. WP/15/105)? Washington, DC: International Monetary Fund. Retrieved from https://www.imf.org/en/Publications/WP/Issues/2016/12/31/How-LargeAre-Global-Energy-Subsidies-42940

Cockburn, J., Robichaud, V., \& Tiberti, L. (2018). Energy subsidy reform and poverty in Arab countries: A comparative CGE-microsimulation analysis of Egypt and Jordan. Review of Income and Wealth, 64(1), 1-31. 
Cooke, E. F. A., Hague, S., Tiberti, L., Cockburn, J., \& Lahga, A. R. E. (2016). Estimating the impact on poverty of Ghana's fuel subsidy reform and a mitigating response. Journal of Development Effectiveness, 8(1), 105-128.

Dabla-Norris, E., Kochhar, K., Suphaphiphat, N., Ricka, F., \& Tsounta, E. (2015). Causes and consequences of income inequality: A global perspective (IMF Staff Discussion Note No. 15/13). Washington, DC: International Monetary Fund. Retrieved from https://www.imf.org/en/Publications/Staff-Discussion-Notes/Issues/2016/12/31/Causesand-Consequences-of-Income-Inequality-A-Global-Perspective-42986

Hakim, R. A., Ismail, R., \& Razak, N. A. A. (2014). Fuel subsidy rationalization: The perils of the middle class in Malaysia. Jurnal Ekonomi Malaysia, 48(2), 83-97.

Hamid, K. A., \& Rashid, Z. A. (2012). Economic impacts of subsidy rationalization Malaysia. In Wu, Y., X. Shi, and F. Kimura (Eds.), Energy market integration in East Asia: Theories, electricity sector and subsidies (ERIA Research Project Report 2011-17). Jakarta: Economic Research Institute for ASEAN and East Asia. Retrieved from http://www.eria.org/Chapter\%209-

Economic\%20Impacts\%20of\%20Subsidy\%20Rationalization\%20in\%20Malaysia.pdf

Harun, M., Mat, S. H. C., Fadzim, W. R., Khan, S. J. M., \& Noor, M. S. Z. (2018). The effects of fuel subsidy removal on input costs of productions: Leontief input-output price model. International Journal of Supply Chain Management, 7(5), 529-534.

Harun, M., Sallahuddin, H, \& Che Mat, S. H. (2018). Pursuing more sustainable energy consumption by analyzing sectoral direct and indirect energy use in Malaysia: An inputoutput analysis. International Journal of Economics and Management, 12(2), 501-210.

Harun, M., Zakariah, A. R., \& Azali, M. (2012). Constructing a social accounting matrix framework to analyse the impact of public expenditure on income distribution in Malaysia. Jurnal Ekonomi Malaysia, 46(2), 63-83.

Hassan, A. A. G., Saari, M. Y., Utit, C., Hassan, A., \& Harun, M. (2016). Penganggaran impak pelaksanaan CBP ke atas kos pengeluaran dan kos sara hidup di Malaysia. Jurnal Ekonomi Malaysia, 50(2), 15-30. doi: 10.17576/JEM-2016-5002-02

Hena, S., Luan, J. D., Rehman, A., \& Zhang, O. X. (2019). A comparative analysis of agricultural development and modernization between China and Pakistan. International Journal of Advanced and Applied Sciences, 6(4), 81-94.

Holland, D., Figueroa, E., \& Gilbert, J. (2001). The role of agriculture and food processing in the Chilean economy: Results from an input-output analysis. Estudios de Economía, 28(2), 293-308.

Khazanah Research Institute (2018). The state of households 2018: Different realities (3 ${ }^{\text {rd }}$ ed.). Kuala Lumpur: Author.

Laderchi, C. R. (2014). Transitional policies to assist the poor while phasing out inefficient fossil fuel subsidies that encourage wasteful consumption. Washington, DC: World Bank.

Lofgren, H., Lee, R. H., \& Robinson, S. (2002). A standard computable general equilibrium (CGE) model in GAMS. Washington, DC: International Food Policy Research Institute.

Loo, S. Y. \& Harun, M. (2019). Fuel subsidy abolition and performance of the sectors in Malaysia: A computable general equilibrium approach. Malaysia Journal of Economic Studies, 56(2), 303-326.

Malaysia, Department of Statistics (2016). Report of Household Income and Basic Amenties Survey 2016. Retrieved from https://www.dosm.gov.my/v1/index.php?r=column/ cthemeByCat\&cat=120\&bul_id=RUZ5REwveU1ra1hGL21JWVIPRmU2Zz09\&menu_i d=amVoWU54UT10a21NWmdhMjFMMWcyZz09 
Nejadrezaei, N. \& Ben-Othmen, M. A. (2019). Rural development as a key to achieve zero hunger in 2030. In Filho, W.L., Azul, A.M., Brandli, L., Özuyar, P.G., \& wall (Eds.), Zero Hunger. Cham: Springer.

Rehman, A., Luan, J. D., Khatoon, R., Iqbal, M. S., \& Hussain, I. (2016). Effect of agricultural growth on poverty reduction, its importance, suggestions. Transylvanian Review, XXIV(5), 449-454.

Rentschler, J. \& Bazilian, M. (2017). Principles for designing effective fossil fuel subsidy reforms. Review of Environmental Economics and Policy, 11(1), 138-155.

Rentschler, J. (2016). Incidence and impact: The regional variation of poverty effects due to fossil fuel subsidy reform. Energy Policy, 96, 491-503.

Samanta, S. K. \& Cerf, J. G. (2009). Income distribution and the effectiveness of fiscal policy: Evidence from some transitional economies. East-West Journal of Economics and Business, XII(1), 29-45.

Sayed, L. E., Sayegh, W., Saliba, E., \& Stephen, J. (2015). Fossil fuel subsidies in Lebanon: Fiscal, equity, economic and environmental impacts. Lebanon: United Nations Development Programme. Retrieved from http://climatechange.moe.gov.lb/viewfile.aspx?id=218

Siddiq, K., Aguiar, A., Grethe, H., Minor, P., \& Walmsley, T. (2014). Impacts of removing fuel import subsidies in Nigeria on poverty. Energy Policy, 69(C), 165-178.

Solaymani, S., Kardooni, R., Kari, F., \& Yusoff, S. (2014). Economic and environmental impacts of energy subsidy reform and oil price shock on the Malaysian transport sector. Trade Behaviour and Society, 2(2).

Solaymani, S., Kari, F., \& Zakaria, R. H. (2013). Evaluating the role of subsidy reform in addressing poverty levels in Malaysia: A CGE poverty framework. The Journal of Development Studies, 50(4), 556-569. doi: 10.1080/00220388.2013.841888

Thiessen, C. (2015). Money in the pocket, food on the table: The economic case for investing in agricultural development. Canadian: Canadian Foodgrains Bank.

Widodo, T., Sahadewo, G. A., Setiastuti, S. U., \& Chaerriyah, M. (2012). Energy market integration in East Asia: Theories, electricity sector and subsidies. In Wu, Y., Shi, X., \& Kimura, F. (Eds), Cambodia's electricity sector in the context of regional electricity market integration (ERIA Research Project Report 2011-17). Jakarta: Economic Research Institute for ASEAN and East Asia.

World Bank (2019). Agriculture and food. Retrieved from https://www.worldbank.org/en/topic/agriculture/overview

Yahoo, M., Zulkeffeli, Z., Rashid, Z. A., \& Puasa, A. F. (2017). A CGE model for assessing the economy-wide effects of removing the cooking oil subsidy in Malaysia. International Journal of Economics, Management and Accounting, 25(3), 491-511. Retrieved from https://journals.iium.edu.my/enmjournal/index.php/enmj/article/view/467 